\title{
Sociological and Communication-Theoretical Perspectives on the Commercialization of the Sciences
}

\author{
Loet Leydesdorff
}

Published online: 3 May 2012

(C) The Author(s) 2012. This article is published with open access at Springerlink.com

\begin{abstract}
Both self-organization and organization are important for the further development of the sciences: the two dynamics condition and enable each other. Commercial and public considerations can interact and "interpenetrate" in historical organization; different codes of communication are then "recombined". However, self-organization in the symbolically generalized codes of communication can be expected to operate at the global level. The Triple Helix model allows for both a neo-institutional appreciation in terms of historical networks of university-industry-government relations and a neo-evolutionary interpretation in terms of three functions: (1) novelty production, (2) wealth generation, and (3) political control. Using this model, one can appreciate both subdynamics. The mutual information in three dimensions enables us to measure the trade-off between organization and self-organization as a possible synergy. The question of optimization between commercial and public interests in the different sciences can thus be made empirical.
\end{abstract}

\section{Introduction}

As an introduction to this topical issue of the "philosophy of commercialized science," the guest editor has listed a number of broad questions at the philosophical level. My own interest in STS (science \& technology studies) and more specifically in the Triple Helix of university-industry-government relations is empirically oriented. However, I agree that the Triple Helix thesis (Etzkowitz and Leydesdorff 2000) relates to philosophical and ethical issues such as the differences between commercialization and entrepreneurship in university-industry relations (Etzkowitz 2002; Mirowski and Sent 2007; Slaughter and Rhoades 2004). Furthermore, the commercialization of quantitative science studies and the development of bibliometric indicators has driven this debate home because of the use of indicators for legitimatory purposes (e.g., Bornmann et al. 2008; Husband Fealing et al. 2011;

L. Leydesdorff $(\bowtie)$

Amsterdam School of Communication Research (ASCoR), University of Amsterdam,

Kloveniersburgwal 48, 1012 CX Amsterdam, The Netherlands

e-mail: loet@leydesdorff.net

URL: http://www.leydesdorff.net 
Mirowski 2010). The interest of journals and publishing houses in improving their "impact factors" or institutions in order to improve their rankings function increasingly as a research incentive in quantitative STS.

In what follows, I develop a sociological perspective inspired by the writing of (Parsons (1968); Luhmann 1990a, b, c). The focus is on their notion of symbolically generalized media of communication: how are scientific discourses codified differently from economic exchange processes or political power relations, and how strongly can such codifications shield domains against differences among domains? I shall argue that codification in interhuman communication does not "close" the discourse or exchange relations operationally, as Luhmann (1995a) argued using a metabiological metaphor (cf. Kuhn 1962; Maturana 1978). Cultural codifications, on the contrary (but under specific conditions), enable us precisely to generate "immutable mobiles" (Latour 1987) within translation processes (Callon and Latour 1981). The concept of hybrid networks can thus be elaborated in terms of networks in which different codes of communication can interact, and potentially generate synergies.

When symbolic generalization ("translation" into "immutable mobiles") is successfully achieved, ${ }^{1}$ diffusion processes in domains other than that of the laboratory can be expected because one no longer needs to "unpack" the black-boxed instruments before using them (Callon 1998). In an empirical study about the emergence and diffusion of two new technoscientific developments- "small interference RNA" (siRNA) and "nanocrystalline solar cells" (NCSC)—Leydesdorff and Rafols (2011), for example, found the difference in terms of socio-cognitive "translatability" across disciplinary borders among specialties to be a crucial factor in moving the development from a disciplinarily oriented Mode- 1 type of research to a transdisciplinary Mode-2 regime (Gibbons et al. 1994).

One can consider such a transition from a local trajectory during the construction phase towards a globalizable regime during the diffusion phase as an "obligatory passage point" for agents (Callon 1986) or a historical path-dependency from an evolutionary perspective (David 1985). In the initial phase, new entrants attach preferentially to the inventor(s) who function as senders of the innovative information. In the later phase, newcomers can be expected to attach preferentially to the "centers of excellence" in which they wish to be received. Such centers can develop oligopolistically a division of labour in the technomarkets of future market potentials and government subsidies.

The change in dynamics in these techno-science-market developments perhaps resembles more closely Schumpeter's (1943) shift from Mark-I to Mark-II (Freeman and Soete 1997) than the notion of a global (that is, system-wide) transition from Mode- 1 to Mode-2 research that has hitherto prevailed in science-policy discussions (Hessels and Van Lente 2008). The process of bottom-up construction can gradually become inverted as the overlay of communications and exchanges above the level of local activities gains momentum and develops its own dynamics. This emerging overlay functions as a receptive feedback (that is, selection mechanism) on the communication dynamics among the senders. Whereas this additional layer of communication may initially add to the uncertainty which prevails, it can be expected to drift (in terms of selection mechanims operating and resonating) towards another steady-state as its attractor and then begin to reduce the prevailing uncertainty as a new regime is increasingly shaped.

The feedback from the emerging next-order regime tends to take over control from bottom-up trajectories. However, the "top-down" dynamics remains a socio-cognitive

1 This symbolic generalization of a specific instance is not yet symbolic generalization at the level of codes of communication. 
construct and therefore fragile, uncertain, and under reconstruction. In my opinion, Luhmann (1995a)socio-cybernetic ideas about the structural coupling of interhuman communication to human agency provide a useful heuristic for the understanding of these evolutionary mechanisms. Furthermore, operationalization can be envisaged using methodologies based on Shannon's (1948) mathematical theory of communication (Krippendorff 1994, 2009; Leydesdorff 2010a, 2011).

\section{Theoretical Background}

The evolutionary metaphor of paradigms and paradigm changes (Kuhn 1962) has revolutionized the empirical study of science and technology as socio-cognitive constructs (Barnes and Dolby 1970; Barnes and Edge 1982). Bloor (1976) notably translated these notions into the "Durkheimian paradigm" of the sociology of scientific knowledge (SSK): scientific knowledge can be considered as "social imagery" of the carrying communities of agents (Douglas 1982). Slezak (1989) noted that from this perspective, the larger (cognitive) variance is explained in terms of the smaller (social) one. Discourse analysis (Mulkay et al. 1983) and the French sociology of translation, however, have deconstructed agency in terms of communication processes, but instead of reversing the arrow for the explanation, the very objective of explanation has been abandoned by these authors in favour of an ethnographic approach (e.g., Latour 1988 and Latour 1992; Leydesdorff 2007; Woolgar and Ashmore 1988).

In my opinion, scientific discourse can be considered as highly-codified communication among intentional human beings; the specific codification (the jargon) enables us to entertain a dynamics in addition to belief systems, namely, as the communication of rationalized expectations. Unlike beliefs that can be attributed to agents or communities of agents, rationalized expectations are attributes of the discourse. They can be entertained and then partially reconstructed by agency. With reference to Husserl's (1935/1936, 1962) phenomenology, Luhmann (1990b, 2002c) emphasized that these constructed constructs rather than the active constructing were to be considered as the driving forces of social evolution.

Luhmann (1995a) took from Maturana (1978) the notion of "operational closure" of the communication and associated this with Kuhn's (1962) notion of "closed" paradigms (cf. Habermas 1987; Leydesdorff 2000). More than other sociologists, Giddens (1976) pointed to the problem of thus favouring concordance in belief structures over discourse when he wrote (at p. 143f.):

\footnotetext{
"exaggeration of the internal unity of paradigms means that the latter tend to be treated by Kuhn as 'closed' systems. This leads to a characterictic difficulty in dealing with meaning-variance between paradigms [...]. How is it possible to get from one meaning-frame to another, if they are separate and self-enclosed universes? [...] In lieu of this, we must substitute, as a starting-point, that all paradigms (read 'language-games', etc.) are mediated by the others. This is so both on the level of the successive development of paradigms within science, and of the actor's learning to 'find his way about' within a paradigm."
}

A similar notion can also be found as an undercurrent in the work of Niklas Luhmann (1977, 1995b, 2002a) when he argues that reflexivity in the communication of meaning allows for "interpenetration" among meaning-processing systems (human agents and interhuman communications). In his philosophy of society, "interpenetration" is considered as an "operational coupling" in the reflexive communication of meaning (Luhmann 1995b, p. 51; Luhmann 2002a, p. 182) which adds to the "structural coupling" between human 
consciousness and communication. The structural coupling between consciousness at the individual level and communication at the above-individual level first closes these two domains operationally. Such closure, for example, enables agents to feel responsibility as "persons" who can act autonomously. Interpenetration as operational coupling among the meaning processing within the two thus distinguished systems enables us to translate locally - that is individually or in organizations - among differently codified communications (Luhmann 1995b, p. 153).

I know that operational closure is more commonly emphasized when reading Luhmann (e.g., Luhmann 2002b; cf. Leydesdorff 2010b)—instead of this operational coupling by way of reflexivity. Operational closure is (meta-)biologically implied in Maturana's (1978) original concept of structural coupling. Künzler (1987) already noted that Luhmann deviated from Parsons by considering coding from the perspective of the biological metaphor of DNA and not sufficiently in terms of language as mediation. In my opinion, one should read Parsons' original idea of symbolic generalization of the codes of communication together with Luhmann's elaboration that these functionally different codes can be expected to span an architecture in the network along eigenvectors of this network. The differentiation in terms of these latent dimensions can be expected to enhance the communication of meaning by symbolically coding from different perspectives. More complexity thus can be processed, and at higher speeds.

However, differentiation and integration are two sides of the same coin. Under empirical conditions the one dynamics may prevail over the other. A high culture, for example, can be considered as mainly an integrated society, such as ancient Egypt or perhaps even 18th-century France. The symbolic integration of France in the anointed body of the King made it necessary to remove his head before a differentiated system guided by Montesquieu's trias politica could be constructed as a Constitution. Political discourse thus became institutionalized as a coordination mechanism of society alongside and in interaction with exchange processes on the market. This social construction in terms of two main coordination mechanisms led historically to a political economy.

A political economy is possible when exchange relations on the market and political communication provide two degrees of freedom for the social coordination. A third coordination mechanism prevailing at the level of society since the 19th century-that is, since the techno-scientific revolution of the period 1870-1910 (Braverman 1974, Noble 1977) — has been the socially organized production of knowledge (Whitley 1984) in research laboratories both in industrial and state-financed settings. The additional option allows for the gradual transition from a political economy to a knowledge-based economy (David and Foray 2002; Foray 2004; Leydesdorff 2006).

Whereas the codes of the communication are different-for example, one cannot buy "truth" with money-and therefore tend toward differentiation, integration implies reduction of complexity by interfacing and translating among the media in historical contexts. Thus, a specific configuration is shaped and reproduced. From the evolutionary or cybernetic perspective, this historical configuration of agency and institutions can be considered as the retention mechanism of a non-linear communication dynamics which further develops in terms of the flows of communications through the networks over time.

Luhmann expressed this trade-off as a kind of dialectics between self-organization of the "free" market forces, and other civil liberties, versus the "enabling and constraining" conditions of historical organization (Giddens 1984). To this dialectics-between selforganization and organization-he added a third mechanism: "interactions". However, in my opinion, he distinguished insufficiently between interactions among human agents (e.g., in face-to-face communications) and interactions among communications as different 
units of analysis. The latter generate the variation in the social system of meaningprocessing.

Elsewhere, I elaborated these three mechanisms-interaction, organization, self-organization-using three different mathematical formalizations of the anticipations implied (Leydesdorff 2008, 2010c). In this context, I need to introduce from that discussion only the difference between historical and evolutionary mechanisms. Historical mechanisms are "phenotypically" observable, whereas evolutionary mechanism can be considered "genotypical". In philosophical terms, one could thus wish to extend the phenomenology of observables (Husserl 1929, 1935/1936; Schütz 1932) with what one might call a more analytical "genomenology" of latent dimensions in interhuman communications. The "genotypes" in this case can be considered as the symbolically generalized codes in the expectations operating when meaning is communicated. The reference to Husserl here is not incidental because meaning is always communicated with reference to horizons of meaning, that is, other possible meanings. Meaning-processing thus can be expected to open up for other possible options when the various meanings can interact.

This proliferation and generation of redundancy-more possibilities - can further be reinforced by using models as in discursive knowledge (Giere 1992, 2006). Models enable us to select and codify specific meanings among possible meanings, and thus to specify expectations. The expectations are about future states which can reflexively be made operational in the present. This use of future states in the present tends to invert the historical arrow of time locally (Coveney and Highfield 1990; Dubois 1998; Prigogine and Stengers 1988). However, this reflexive inversion operates in history and therefore leaves an empirically contingent footprint.

One should not reify "self-organization" as Greek gods who intervene in our lives. The models remain constructs, but the codified and symbolically generalized character of the communications can change their status from historical mechanisms - that is, at the level of trajectories - to evolutionary mechanisms operating at the level of regimes (Dosi 1982). In Capital I, for example, Marx (1867) went to great lengths to explain why the exchange of commodities by the mediation of money ("Ware-Geld-Ware" or WGW) is different from the exchange of money via the mediation of commodities ("Geld-Ware-Geld" or GWG). ${ }^{2}$ The latter mechanism is more abstract and thus able to take over evolutionary control under the condition of modern capitalism.

Similarly, in science-albeit perhaps less frequently than the daily transactions on the market - the submission of a knowledge claim (usually in the form of a manuscript) brings the context of justification into operation within the context of discovery in which this new insight had previously been entertained. The epistemological status of the knowledge content under discussion is thus changed. From a communication-theoretical perspective (cf. Popper [1935]1959), the "context of justification" remains socially contingent (composed, for example, of editors, referees, publishing houses, etc.), but the medium of communication has changed, and accordingly the rules of the game are changed. Note that the one subdynamics does not replace the other, but control may shift from the one to the other level, and back! The context of discovery remains needed for providing the variation, but it operates with a speed different from the context of justification (Simon 1973).

In my opinion, this conceptualization in terms of different dynamics operating upon each other opens a realm of empirical questions. The symbolically generalized codes of communication function as auto-regenerative mechanisms because they are anchored in a multitude of dimensions in interhuman communication. Codification operates by

\footnotetext{
2 "Ware-Geld-Ware" can be translated as "Commodigy-Money-Commodity" (Marx 1995, pp. 66 ff.).
} 
deselecting most modalities and enhancing only one or a few. For example, education is codified differently from research. Political discourse is different from scholarly discourse and one is not supposed to pay one's way into a scholarly publication. A submission fee, for example, can be expected to have more symbolic meaning than value.

However, the digital turn in communication, which allows for entrepreneurship beyond the printing of journals, has witnessed more recently the emergence of full author fees as financial coverage for publication costs (Wyatt 2010). If all journals were author-feebased-against subscription-based — the science system as a self-organizing system might become driven exclusively by institutional and commercial concerns. Since not everyone is able to pay such a fee, control over access could shift to mechanisms other than self-regulation at the level of the scientific community (Wagner 2008).

The question of this theme issue is, from this perspective, whether such a change at the control level has indeed occurred or might be occurring at present. From my structuralist perspective, I would not expect this shift to prevail in the longer run because differentiation and self-organization allow for greater complexity of the communication, whereas control and integration require organization from a perspective that reduces complexity (e.g., in terms of management objectives). But under historical conditions one may find situations where integrating organization (e.g., state or industrial control) is dominant over open competition and differentiating self-organization. For example, possibilities of global expansion and phases of shrinking and retention can be expected to alternate in complex waves (Schumpeter [1939], 1964, pp. 175f.).

\section{Two Triple Helix Models: An Institutional and Evolutionary Version}

The Triple Helix of university-industry-government relations offers a rich empirical model because one can examine these relations in terms of institutional arrangements using a neoinstitutional perspective, and then study collaboration patterns using, for example, social network analysis. For example, one can determine the extent to which universities are central nodes in the networks (Godin and Gingras 2000) using centrality indicators (de Nooy et al. 2005). Institutional arrangements develop historically, that is, with the arrow of time. The institutional perspective thus allows for ranges of historical case-studies on the basis of which one can develop hypotheses about the underlying dynamics of cultural evolution (e.g., Etzkowitz et al. 2000).

The main advantage of using the Triple Helix model from this (neo)institutional perspective is, in my opinion, that none of the three contexts are externalized on a priori grounds. For example, government configurations and interventions matter for universityindustry relations. Furthermore, the endogenization of techno-scientific developments into the analysis of the political economy has unavoidably led to a shift away from neo-classical assumptions about equilibrium-seeking and towards a perspective on fluxes in evolutionary economics (Nelson and Winter 1977; Dosi 1982). The dynamics of a knowledge-based economy are in important respects different from those of a political economy (Schumpeter 1912; Leydesdorff 2006).

The alternative of an evolutionary appreciation of the Triple Helix model focuses on the three functional dynamics carried by these institutions and their networks: (1) wealth generation, (2) novelty production, and (3) political control. These three functions have, in my opinion, to be invoked and thus to operate as social coordination mechanisms in the case of innovation. Social functions, however, can be deconstructed using Luhmann's 
perspective (as a critique of Parsons' structural-functionalism (Luhmann 1975)) in terms of differently coded and symbolically generalized media of communication.

Parsons (1963a, b, 1968) was the first to propose symbolic generalization, but he did not identify symbolic generalization in the codes of communication as potential drivers of the differentiation in social systems, although he understood that codes operate latently (Lazarsfeld and Henry 1968). This latency provides the symbolically generalized codes with the status of "genotypes:" the social system is replicated in terms of coding of the expectations, wheras the "phenotypical" units of interaction can be expected to operate in terms of (institutional) agency. The "phenotypes" are necessarily historical (Hodgson and Knudsen 2011).

As against a double helix, a Triple Helix is sufficiently complex to contain all these kinds of non-linear behavior. The "double helix" can first be considered as a co-evolutionary model that allows, among other things, for "mutual shaping" and thus for the emergence of historical trajectories. These trajectories may be "locked-in" into a regime when the third helix is relatively stable. For example, the constitutional stability of nation states (after the period of gestation from 1848 to 1870) allowed for the construction of national systems of innovation during the 20th century. Government procurement systems in the health or energy sector may weaken the market and innovation because of the imposed selection of specific technologies (Hughes 1983). Similary, the Soviet Union, controlling the market from a centralized perspective, could not maintain its innovative edge during the Cold War.

As yet, there is no prescription for the right mix among the coordination mechanisms: China has been extremely successful after introducing its "market system" at the 14th Congress of the Communist Party in 1991 (Leydesdorff and Guoping 2001). In this system, the role of government in guiding techno-economic developments is much stronger than is typical for Western democracies. Although more recently the emphasis in government funding has shifted towards "business expenditure on R\&D" (BERD in OECD terminology; cf. OECD 1963, 1976), the boom in scientific publishing during the period 1995-2005 was based on the funding of academic research (that is, "higher eduction expenditure on R\&D" and "government intramural expenditure on R\&D"; cf. Shelton and Leydesdorff 2012).

Is the Triple Helix a sufficiently complex model to explain these phenomena? Why would one not add "the public" as a fourth helix, "sustainability" as a fifth, etc., as has been suggested by colleagues and in the literature (e.g., Carayannis and Campbell 2009, 2010). I would argue that one would expect a whole alphabet of relevant dimensions to operate in a complex system such as interhuman communications (Simon 1973). However, three of them seem currently to be generalized symbolically to such an extent that they can globally carry the knowledge-based development of the social system.

For reasons of parsimony, in my opinion, one should be cautious in generalizing beyond the Triple Helix model to an $N$-tuple of helices so long as one is not able to operationalize and show development in the relatively simple case of three dimensions (Leydesdorff 2012). Dimensions other than economic transactions, political power, and scientific truthfinding may yet not be sufficiently codified and globalized, but perhaps can be further developed in future stages of cultural evolution. Luhmann et al. (2004), for example, also distinguished law as an autopoietic subsystem, along with love (Luhmann 1986) and art (Luhmann 2000). From a methodological perspective, the issues are already quite complex with three subdynamics, although I began to explore the working of a fourth helix (of international collaborations) in a study about Japan (Leydesdorff and Sun 2009) followed most recently by one about Korea (Kwon et al. 2012). 
In the Japanese case, for example, our results suggested that despite strong government incentives and the prevailing rhetoric, over the last three decades university-industry relations have steadily declined in terms of coauthorship relations. International coauthorship, however, has steadily increased in all three helices, but particularly among academics. After the changes at the global level brought about by the demise of the Soviet Union and the opening of China to the market system in 1991, the synergy between the international relations of Japanese authors and their national Triple-Helix relations gradually increased.

In some cases, university and industrial researchers in Japan are indirectly linked by foreign coauthorship relations from which the Japanese system at the aggregated level is able to profit as a retention mechanism. We did not find such a change using Canadian data, because mobility in international relations with the USA has always been immensely important in Canada, nor for Korea, because the political direction of the Korean government controls the science system more intensively between elections (Park and Leydesdorff 2010).

\section{What is the Position of the University?}

Shinn (2002) noted that the strength of the Triple Helix model is its focus on university relations because the university can be expected to play a crucial role in the long-term dynamics of the knowledge-based system given the steady stream of students as influx and output to the labour market. Is the university as an institution changing because of commercial pressures, changes (e.g., cuts) in government funding, entrepreneurial activities (such as patents, licensing, spin-offs, etc.)? Is there a tendency to provide funding for elite universities as against rank-and-file state universities that focus primarily on mass education?

In a comprehensive study of university publishing comparing various rankings, Halffman and Leydesdorff (2010) found a global decrease of differentiation among universities. Universities increasingly seem to be involved in a global regime of competition that sets imperatives and therefore tends to lead to institutional isomorphism (Powell and DiMaggio 1991). Leydesdorff and Meyer (2010) noted that after a long period of growth, university patenting reached a plateau and may even be on the decline since the mid-2000s. Whether we are witnessing "the End of the Bayh-Dole Effect" as this contribution was entitled with reference to the Bayh-Dole Act of 1981 in the USA, remains to be seen given recent changes in the finance system. However, it seems to me that the main reason for these longterm changes could be the pressures of global ranking to which universities are now subjected as another selection environment. Rankings take high-quality publications into account, but usually do not attribute much weight to patenting and commercial activities.

In summary, selection environments that differ from natural selection are dynamic and can be expected to differentiate when the relevant environments become more complex. In evolutionary economics, one first distinguished between market and non-market selection environments (Nelson and Winter 1982). This has changed evolutionary theorizing because from a biological perspective one cannot distinguish easily between natural and non-natural selection environments without leaving the Darwinian paradigm. (This discussion has led to a debate about Lamarckian evolution, but Hodgson and Knudsen (2011) have shown convincingly that this line of argument can be considered a red herring.)

The specification of different selection environments can only be done in the form of hypotheses because selection environments operate negatively and cannot be directly 
observed. Variation can be observed historically; the specification of a selection mechanism remains a theoretically informed hypothesis. Andersen (1994) noted that Nelson and Winter (1982) and the cohort of neo-Schumpeterian scholars following them failed to specify "what is evolving?" in their systems view. Therefore, this type of "historyfriendly" modelling (Malerba et al. 1999) tends to degenerate into a theory of the firm as the observable units of analysis (e.g., Casson 1997). However, firms are carriers of the system at the phenotypical level and thus do not "evolve," but at best compete with one another.

What evolves, in my opinion, are the functionally differentiated coordination mechanisms in interhuman communication. These systems are functionally different in terms of their codes of communication. Freedom to recombine these codes is needed for innovation. A coevolutionary model of (technological) supply and (market) demand is insufficiently complex because a Triple Helix of economic exchanges, power relations, and knowledge production is involved. The third (sub)dynamics may stabilize or destabilize an equilibrium dynamics between the other two. Destabilization of non-natural selection mechanisms may lead to meta-stabilization, hyper-stabilization in a lock-in, and/or globalization. The transition from a trajectory (e.g., Mode-1) to a regime (e.g., Mode-2) is then a systems effect which can no longer be attributed to individual intentions or specific actions.

\section{The Formal Triple Helix Model}

In another branch of mathematical biology, mutual information in three dimensions was used by Ulanowicz (1986, at pp. 143f.) to develop Ascendency Theory in ecology. This information measure had been around in information theory, where it was mainly used for modelling the interactions among alphabets as different codes (Abramson 1963) or as a non-parametric alternative to three-way interaction effects in the variance (McGill 1954). The particularity of the measure is that it can become negative.

Shannon (1948) first proposed considering (and measuring) information counter-intuitively as uncertainty. For example, if all bets are off in a 50-50 chance process, this provides us with precisely one bit of information. Shannon-type information is by definition positive. Krippendorff (2009) showed that the mutual information in three (or more) dimensions can therefore no longer be considered as Shannon-type information. Yeung (2008) proposed to consider it as a signed information measure.

Since information is defined as positive uncertainty in this tradition, a negative information content would reduce uncertainty. In operation, however, overall uncertainty necessarily increases - analogously to the second law in thermodynamics (Theil 1972) and a reduction of uncertainty or, in other words, an increase in redundancy can only be caused by the generation of a larger maximum information content in the system (Brooks and Wiley 1986). The maximum information content of a system is by (Shannon's) definition equal to the logarithm of the number of options available.

It can perhaps be debated whether in natural evolution the number of options continuously increases, but in cultural evolution, under the condition of functional differentiation among the codes of communication, this number proliferates because the same events can be provided with different meanings. Furthermore, as noted, meanings refer to horizons of meaning which can also be expanded over time. The expansion of horizons of meaning is generated by next-order models of the meanings constructed hitherto. The techno-sciences (e.g., ICT) are powerful drivers in generating new meaning that, if successful, can be used for innovating systems that were previously considered as "naturally given". 
Technological developments may outmode and overwrite previous generations of technology. Thus, an evolutionary pump of redundancy is generated by the self-organization of the techno-sciences.

Similarly, the coding of transactions in the economy in terms of money, credit, stocks, etc. adds layers to the possibilities of economic exchanges. The trias politica enriches political and legal discourse with dimensions of potentially different meanings. In general, the proliferation of fantasies and wishes grows faster than the options that can historically be realized (Weinstein and Platt 1969). The crucial question becomes: what can be retained as synergy —at the social level! —-from these interactions among expectations? How should the institutional make-up of a knowledge-based system be arranged reflexively?

In the end, these are also normative questions, but the analytical angle of the mutual information in three dimensions provides us with an access that can inform the discourse. It could be shown (Krippendorff 2009; Leydesdorff 2010a) that this potentially negative measure provides us with a difference; namely, the difference between the historically generated (Shannon-type) interaction information and the redundancy-that is, the number of options-generated in loops of reflexive (interhuman) communication. This difference can either add to the uncertainty in the historical system or reduce the prevailing uncertainty, in accordance with the sign of the measure.

Let me offer the simple example of a family consisting of a mother, a father, and a child. If there is synergy in this family system, the child may address a question either to the father or to the mother, but the answers will not be confusing. One can in such a case assume an a priori synchronization between the possible answers of both parents. The child has no access to this synchronization, but this latent structure reduces the prevailing uncertainty. Similarly, in the case of a divorce this system may break down and the structure in the communication may become complex and confusing.

Analogously, in university-industry-government relations: structural relationships between any two partners can emerge and can be dissolved. Is there synergy among the fluxes of communication carrying differently codified meanings, and can this be measured as a reduction of prevailing uncertainty at the systems level? Let me hasten to say that this is a longer-term research program that is not yet fully understood in terms of all the methodological problems involved (e.g., Leydesdorff 2010a; De Nooy and Leydesdorff 2009), including its status in relation to possible alternatives such as measuring interaction effects in three-way logit models. Using different proxies, however, we have applied this model to the Dutch, German, and Hungarian innovation systems and the results have been fruitful in terms of heuristics.

For example, in the Dutch system this synergy can be found at the national level, whereas in Germany it can be found at the level of the federal states (Leydesdorff and Fritsch 2006; Leydesdorff et al. 2006). In Hungary, the system has lost its systemic character at the national level: after the changes of the 1990s the western part was increasingly integrated into the dynamics of Western Europe; greater Budapest has become a metropolitan innovation system; and the eastern part is still controlled by the dynamics of the old state-led innovation system (Lengyel and Leydesdorff 2011). In a recent study (Strand and Leydesdorff in preparation) yet another pattern was visible in Norway.

The Triple Helix indicator is available as a computer program at http://www. leydesdorff.net/th2/th.exe. One can play with the program and see in which configurations the $T$-values ( $T$ for transmission) in three dimensions become negative and/or positive. This adds to my argument that the synergy from university-industry-government relations is based on specific trade-offs between expectations and institutionalizations, and should not be answered by sweeping statements about the "enterpreneurial university" or the 
increased threat of commercialization. Such idealizations exaggerate by using ideal-typical metaphors.

Indeed, the use of such claims, for example, in public relations, may indicate a problem. For example, in the Netherlands, the Technical University of Twente (in Enschede) advertises itself as "entrepreneurial" whereas various indicators show that the Technical University in Eindhoven may have a stronger record in this respect. The structural aspects of the Einhoven region favour such a role, whereas this synergy has been absent in Twente (Leydesdorff et al. 2006). Using patent analysis-perhaps, to be considered as a proxy for commercialization-Leydesdorff and Bornmann (2012), for example, found Enschede only in the top- $25 \%$ of Dutch cities, whereas Eindhoven had by far the largest score among the cities in the top-1\%.

\section{Interpenetration, Interaction, and Interfacing}

Commercialization can be (1) ad hoc in interactions between academia and industry, (2) structural in the organization at interfaces of a knowledge-based arrangement, and (3) it may affect the cognitive core of the scientific development or remain mainly a condition. The concern is mainly about the third category: Do interactions and interfaces lead to interpenetration of commercial considerations into the process of science itself and if so to what extent? Can they become so dominant that scientific disciplines or specialties are locked-in?

Unlike Parsons, who used "interpenetration" as a term for any cross-cutting between cultural expectations and social structures (e.g., Parsons and Platt 1973, at p. 36), Luhmann reserved this word for the reflexive coupling that is additionally possible because of reflexivity between the structurally coupled layers of interhuman communication and human consciousness. In his model, the performatively functional subsystems of communication (the economy, science, politics, etc.) do not interpenetrate one another, but merely disturb one another in what Luhmann et al. (2004) - in my opinion, erroneously ${ }^{3}$ considered as yet another structural coupling.

The social system operates in terms of translations among its subsystems which can each be expected to perform their own autopoiesis (under the condition of modernity). Luhmann (1990b, at pp. 635 ff.) provided an amazingly precise specification of this mechanism, but he labeled it differently (cf. Leydesdorff 2011). Let me cut this discussion short by summarizing my own model: the symbolically generalized codes of communication span the social system in perpendicular directions, like in an orthogonally rotated factor model. However, this remains an analytical reconstruction of the social constructs that can be entertained implicitly or explicitly by both analysts and the participating agents who exist under historical conditions.

The observables are contained in a historical "life-world". As with factor loadings or factor scores, manifestations are never "pure" factors, but always based on trade-offs. The analyst (as against the participant) may be able to claim additional knowledge on the basis of his or her particular perspective, but scholarly discourse develops as an evolutionarily next-order mechanism of communication (for example, in the "context of justification") that emerges from and loops into the local level. All codes of communication can historically be interfaced and interact at the level of organizations.

\footnotetext{
3 In my opinion, the functional subsystems are not structurally coupled, but structurally part of the social system and therefore operationally coupled, namely, coupled whenever the social system operates.
} 
When further formalized - that is, as decisions are increasingly taken according to interpersonal criteria and decision rules-organization itself can also be developed as yet another symbolically encoded subsystem of communication (Achterbergh and Vriens 2009; Leydesdorff 2006, at pp. 149 ff.). Its historicity, however, remains as a footprint in the further development of interhuman communication systems. These institutional footprints enable us to retain wealth from knowledge.

Finally, "interaction" can be a confusing concept when the interacting units are not sufficiently specified. In this context of organization and self-organization of the expectations in communication systems, interactions among expectations can be considered as generating the variation in this system. Variation is crucial, for example, for making the system more complex and hence eventually more knowledge-based. From this perspective, the empirical question is whether and to what extent commercialization can be expected to provide us with new opportunities to raise new scientific questions, articulate demand, etc.?

\section{Conclusions}

I hesitated to call my perspective a "sociological" one. Perhaps "communication-theoretical" might be better because of the use of this perspective in Luhmann's sociology of communication and Shannon's mathematical theory of communication. Unfortunately, large parts of sociology, particularly in Europe (and notably in STS), have abandoned the structural perspective because structure has been associated with reification (Ashmore 1989; Latour 1988; Woolgar 1988). I have argued that the latent functions that can be hypothesized can also be deconstructed as interhuman communication systems operating with a wealth of potential codifications.

The interhuman communication of meaning (as different from and additional to the communication of information) provides events with predicates that are culturally constructed (Husserl 1929). Sociologists have begun to explore this new domain empirically (Berger and Luckmann 1966; Schütz 1932), theoretically (Luhmann 1995a), and methodologically (Leydesdorff 2010a, c, 2011). The interactions among the different codes operating in economic transactions, political power relations, and scientific validation have been leading me further to develop a possible explanation for a knowledge-based economy (Leydesdorff and Zawdie 2010).

How does this research programme relate to the concern expressed in the title of this topical issue, namely, "the philosophy of commercialized science?" In my opinion, this claim can itself perhaps be considered as a social text. I envisage that others in this collection may address the debate about Newton's position ignited by Boris Hessen's (1931) famous challenge to show the material interests in Newton's working life (Basalla 1968). In action and historical organization the different codes of communication are always historically integrated in a specific organizational format. This integration may be suffocating - as it probably was not in the case of Newton, but most likely was in the case of Lysenko (Graham 1974; Lecourt 1976).

Codifications compete evolutionarily as "genotypes" in interhuman communications, but all "genotypes" can be expected to remain available during the replication. Human agents or institutional agents (e.g., firms) are not the evolving units in cultural evolution, but our communication structures are. One would not be able to pay with a credit card in ancient Rome, but perhaps one could understand the Latin. The Latin has remained the same, but the codification of economic transactions was further developed. 
The commercialization of the sciences can be considered as the phenotypical result of interactions, interfacing, and interpenetration among these differently coded communications in historical configurations (Hessels et al. 2011). One can expect the synergetic effects of these interactions, interfaces, and interpenetrations to differ among sciences, regions, countries, etc. Thus, the themes of university-industry-government relations and the (potential) effects of commercialization offer a rich domain for empirical research. For example, at some places (e.g., in Eastern Hungary) more opening to the markets may be desirable, while at other places the configurations of interests tend to drive the organizational dynamics into a lock-in as a hyper-stabilization instead of allowing for meta-stabilization and self-organization of communications as a concurrently possible dynamic (Dolfsma and Leydesdorff 2009; Leydesdorff and Zawdie 2010).

Acknowledgments I am grateful to Iina Hellsten, Laurens Hessels, Caroline Wagner, and Sally Wyatt for comments on a draft version of this paper.

Open Access This article is distributed under the terms of the Creative Commons Attribution License which permits any use, distribution, and reproduction in any medium, provided the original author(s) and the source are credited.

\section{References}

Abramson, N. (1963). Information theory and coding. New York: McGraw-Hill.

Achterbergh, J., \& Vriens, D. (2009). Organizations: Social systems conducting experiments. Dordrecht: Springer Verlag.

Andersen, E. S. (1994). Evolutionary economics: Post-schumpeterian contributions. London: Pinter.

Ashmore, M. (1989). The reflexivity thesis: wrighting sociology of scientific knowledge. Chicago and London: Chicago University Press.

Barnes, S. B., \& Dolby, R. G. A. (1970). The scientific ethos: A deviant viewpoint. European Journal of Sociology, 11(1), 3-25.

Barnes, B., \& Edge, D. (Eds.). (1982). Science in context. Cambridge, MA: MIT Press.

Basalla, G. (Ed.). (1968). The rise of modern science: Internal or external factors?. Lexington, MA: Heath and Cy.

Berger, P. L., \& Luckmann, T. (1966). The social construction of reality: A treatise in the sociology of knowledge. Garden City: Doubleday.

Bloor, D. (1976). Knowledge and social imagery. London: Routledge \& Kegan Paul.

Bornmann, L., Mutz, R., Neuhaus, C., \& Daniel, H. D. (2008). Citation counts for research evaluation: Standards of good practice for analyzing bibliometric data and presenting and interpreting results. Ethics in Science and Environmental Politics (ESEP), 8(1), 93-102.

Braverman, H. (1974). Labor and monopoly capital. The degradation of work in the twentieth century. New York, London: Monthly Review Press.

Brooks, D. R., \& Wiley, E. O. (1986). Evolution as entropy. Chicago, London: University of Chicago Press.

Callon, M. (1986). The sociology of an actor network: The case of the electric vehicle. In M. Callon, J. Law, \& A. Rip (Eds.), Mapping the dynamics of science and technology (pp. 19-34). London: Macmillan.

Callon, M. (1998). The laws of the market. Oxford and Malden, MA: Blackwell.

Callon, M., \& Latour, B. (1981). Unscrewing the big Leviathan: how actors macro-structure reality and how sociologists help them to do so. In K. D. Knorr-Cetina \& A. V. Cicourel (Eds.), Advances in social theory and methodology.toward an integration of micro- and macro-sociologies (pp. 277-303). London: Routledge \& Kegan Paul.

Carayannis, E. G., \& Campbell, D. F. J. (2009). 'Mode 3' and 'quadruple helix': toward a 21st century fractal innovation ecosystem. International Journal of Technology Management, 46(3), 201-234.

Carayannis, E. G., \& Campbell, D. F. J. (2010). Triple helix, quadruple helix and quintuple helix and how do knowledge, innovation, and environment relate to each other? International Journal of Social Ecology and Sustainable Development, 1(1), 41-69.

Casson, M. (1997). Information and organization: A new perspective on the theory of the firm. Oxford: Clarendon Press. 
Coveney, P., \& Highfield, R. (1990). The arrow of time. London: Allen.

David, P. A. (1985). Clio and the economics of QWERTY. American Economic Review, 75, 332-337.

David, P. A., \& Foray, D. (2002). An introduction to the economy of the knowledge society. International Social Science Journal, 54(171), 9-23.

De Nooy, W., \& Leydesdorff, L. (2009). How can configurations be studied in 2-mode networks? Configurational information and "structuration". Paper presented at the two-mode social network analysis conference, Free University Amsterdam, October 1-2, 2009.

De Nooy, W., Mrvar, A., \& Batagelj, V. (2005). Exploratory social network analysis with pajek. New York: Cambridge University Press.

Dolfsma, W., \& Leydesdorff, L. (2009). Lock-in \& break-out from technological trajectories: Modeling and policy implications. Technological Forecasting and Social Change, 76(7), 932-941.

Dosi, G. (1982). Technological paradigms and technological trajectories: A suggested interpretation of the determinants and directions of technical change. Research Policy, 11(3), 147-162.

Douglas, M. (1982). Essays in the sociology of perception. London: Routledge \& Kegan Paul.

Dubois, D. M. (1998). Computing anticipatory systems with incursion and hyperincursion. In D. M. Dubois (Ed.), Computing anticipatory systems, CASYS-first international conference (Vol. 437, pp. 3-29). Woodbury, NY: American Institute of Physics.

Etzkowitz, H. (2002). MIT and the rise of entrepreneurial science. London: Routledge.

Etzkowitz, H., \& Leydesdorff, L. (2000). The dynamics of innovation: From national systems and 'Mode 2' to a triple helix of university-industry-Government relations. Research Policy, 29(2), 109-123.

Etzkowitz, H., Webster, A., Gebhardt, C., \& Terra, B. R. C. (2000). The future of the university and the university of the future: Evolution of ivory tower to entrepreneurial paradigm. Research Policy, 29(2), $313-330$.

Foray, D. (2004). The economics of knowledge. Cambridge, MA/London: MIT Press.

Freeman, C., \& Soete, L. (1997). The economics of industrial innovation. London: Pinter.

Gibbons, M., Limoges, C., Nowotny, H., Schwartzman, S., Scott, P., \& Trow, M. (1994). The new production of knowledge: The dynamics of science and research in contemporary societies. London: Sage.

Giddens, A. (1976). New rules of sociological method. London: Hutchinson.

Giddens, A. (1984). The constitution of society. Cambridge: Polity Press.

Giere, R. N. (Ed.). (1992). Cognitive models of science (Minnesota studies in the philosophy of science, Vol. XV).. Minneapolis: University of Minnesota.

Giere, R. N. (2006). Scientific perspectivism. Chicago, IL: University of Chicago Press.

Godin, B., \& Gingras, Y. (2000). The place of universities in the system of knowledge production. Research Policy, 29(2), 273-278.

Graham, L. R. (1974). Science and philosophy in the Soviet Union. New York: Vintage Books.

Habermas, J. (1987). Excursus on Luhmann's appropriation of the philosophy of the subject through systems theory. In The Philosophical Discourse of modernity: Twelve lectures (pp. 368-385). Cambridge, MA: MIT Press.

Halffman, W., \& Leydesdorff, L. (2010). Is inequality among universities increasing? Gini coefficients and the elusive rise of elite universities. Minerva, 48(1), 55-72.

Hessels, L. K., Grin, J., \& Smits, R. E. H. M. (2011). The effects of a changing institutional environment on academic research practices: Three cases from agricultural science. Science and Public Policy, 38(7), 555-568.

Hessels, L. K., \& van Lente, H. (2008). Re-thinking new knowledge production: A literature review and a research agenda. Research Policy, 37(4), 740-760.

Hessen, B. (1931). The social and economic roots of Newton's principia. In Science at the cross roads (pp. 41-101). London: Kniga.

Hodgson, G., \& Knudsen, T. (2011). Darwin's conjecture: The search for general principles of social and economic evolution. Chicago, London: University of Chicago Press.

Hughes, T. P. (1983). Networks of power: electrification in Western society, 1880-1930. Baltimore, MD: Johns Hopkins University Press.

Husband Fealing, K., Lane, J. I., Marburger, J. H., I. I. I., \& Shipp, S. S. (Eds.). (2011). The science of science policy: A handbook. Stanford, CA: Stanford Business Books.

Husserl, E. (1929). Cartesianische Meditationen und Pariser Vorträge [Cartesian meditations and the Paris lectures] (p. 1973). The Hague: Martinus Nijhoff.

Husserl, E. (1935/1936). Die Krisis der Europäischen Wissenschaften und die Transzendentale Phänomenologie. Den Haag: Martinus Nijhoff, 1962.

Krippendorff, K. (1994). A recursive theory of communication. In D. Crowley \& D. Mitchell (Eds.), Communication theory today (pp. 78-104). Cambridge, UK: Polity Press. 
Krippendorff, K. (2009). Information of interactions in complex systems. International Journal of General Systems, 38(6), 669-680.

Kuhn, T. S. (1962). The structure of scientific revolutions. Chicago: University of Chicago Press.

Künzler, J. (1987). Grundlagenprobleme der Theorie symbolisch generalisierter Kommunikationsmedien bei Niklas Luhmann. Zeitschrift für Soziologie, 16(5), 317-333.

Kwon, K. S., Park, H. W., So, M., \& Leydesdorff, L. (2012). Has globalization strengthened South Korea's National Research System? national and international dynamics of the triple helix of scientific co-authorship relationships in South Korea. Scientometrics, 90(1), 163-175.

Latour, B. (1987). Science in action. Milton Keynes: Open University Press.

Latour, B. (1988). The politics of explanation: An alternative. In S. Woolgar \& M. Ashmore (Eds.), Knowledge and reflexivity: New frontiers in the sociology of knowledge (pp. 155-177). London: Sage.

Latour, B. (1992). One more turn after the social turn. In E. McMullin (Ed.), The social dimensions of science (pp. 272-294). Notre Dame, IN: Notre Dame Press.

Lazarsfeld, P. F., \& Henry, N. W. (1968). Latent structure analysis. New York: Houghton Mifflin.

Lecourt, D. (1976). Lyssenko: "Histoire Réelle d'une "Science Prolétarienne”. Paris: Maspero.

Lengyel, B., \& Leydesdorff, L. (2011). Regional innovation systems in Hungary: The failing synergy at the national level. Regional Studies, 45(5), 677-693.

Leydesdorff, L. (2000). Luhmann, Habermas, and the theory of communication. Systems Research and Behavioral Science, 17(3), 273-288.

Leydesdorff, L. (2006). The knowledge-based economy: Modeled, measured, simulated. Boca Raton, FL: Universal Publishers.

Leydesdorff, L. (2007). Scientific communication and cognitive codification: Social systems theory and the sociology of scientific knowledge. European Journal of Social Theory, 10(3), 375-388.

Leydesdorff, L. (2008). The communication of meaning in anticipatory systems: A simulation study of the dynamics of intentionality in social interactions. In D. M. Dubois (Ed.), Proceedings of the 8th international conference on computing anticipatory systems CASYS'07 (Vol. 1051, pp. 33-49). Melville, NY: American Institute of Physics Conference Proceedings.

Leydesdorff, L. (2010a). Redundancy in systems which entertain a model of themselves: interaction information and the self-organization of anticipation. Entropy, 12(1), 63-79. doi:10.3390/e12010063.

Leydesdorff, L. (2010b). Luhmann reconsidered: Steps towards an empirical research program in the sociology of communication. In C. Grant (Ed.), Beyond universal pragmatics: Essays in the philosophy of communication (pp. 149-173). Oxford Peter Lang.

Leydesdorff, L. (2010c). The communication of meaning and the structuration of expectations: Giddens' "structuration theory" and Luhmann's "self-organization". Journal of the American Society for Information Science and Technology, 61(10), 2138-2150.

Leydesdorff, L. (2011). "Meaning" as a sociological concept: A review of the modeling, mapping, and simulation of the communication of knowledge and meaning. Social Science Information, 50(3-4), $1-23$.

Leydesdorff, L. (2012). The triple helix, quadruple helix,..., and an $N$-tuple of helices: Explanatory models for analyzing the knowledge-based economy? Journal of the Knowledge Economy, 3(1), 25-35.

Leydesdorff, L., \& Bornmann, L. (2012). Mapping (USPTO) patent data using overlays to Google Maps. Journal of the American Society for Information Science and Technology (in press); available at http://arxiv.org/abs/1110.5712.

Leydesdorff, L., Dolfsma, W., \& Van der Panne, G. (2006). Measuring the knowledge base of an economy in terms of triple-helix relations among 'technology, organization, and territory'. Research Policy, 35(2), 181-199.

Leydesdorff, L., \& Fritsch, M. (2006). Measuring the knowledge base of regional innovation systems in germany in terms of a triple helix dynamics. Research Policy, 35(10), 1538-1553.

Leydesdorff, L., \& Guoping, Z. (2001). University-industry-government relations in China: An emergent national system of innovation. Industry and Higher Education, 15(3), 179-182.

Leydesdorff, L., \& Meyer, M. S. (2010). The decline of university patenting and the end of the Bayh-Dole effect Scientometrics, forthcoming, doi10.1007/s11192-11009-10001-11196.

Leydesdorff, L., \& Rafols, I. (2011). How do emerging technologies conquer the world? An exploration of patterns of diffusion and network formation. Journal of the American Society for Information Science and Technology, 62(5), 846-860.

Leydesdorff, L., \& Sun, Y. (2009). National and international dimensions of the triple helix in japan: university-industry-Government versus international co-authorship relations. Journal of the American Society for Information Science and Technology, 60(4), 778-788.

Leydesdorff, L., \& Zawdie, G. (2010). The triple helix perspective of innovation systems. Technology Analysis \& Strategic Management, 22(7), 789-804. 
Luhmann, N. (1975). Einführende Bemerkungen zu einer Theorie symbolisch generalisierter Kommunikationsmedien. Soziologische Aufklärung (Vol. 2, pp. 170-192). Opladen: Westdeutscher Verlag.

Luhmann, N. (1977). Interpenetration: Zum Verhältnis personaler und sozialer Systeme. Zeitschrift für Soziologie, 6(1), 62-76.

Luhmann, N. (1986). Love as passion: The codification of intimacy. Stanford, CA: Stanford University Press.

Luhmann, N. (1990a). The cognitive program of constructivism and a reality that remains unknown. In W. Krohn, G. Küppers \& H. Nowotny (Eds.), Selforganization. Portrait of a scientific revolution (pp. 64-85). Dordrecht: Reidel.

Luhmann, N. (1990b). Die Wissenschaft der Gesellschaft. Suhrkamp: Frankfurt a.M.

Luhmann, N. (1990c). Meaning as sociology's basic concept. In N. Luhmann (Ed.) Essays on self-reference (pp. 21-79). New York, Oxford: Columbia University Press.

Luhmann, N. (1995a). Social systems. Stanford, CA: Stanford University Press.

Luhmann, N. (1995b). Soziologische Aufklärung 6. Opladen: Westdeutscher Verlag.

Luhmann, N. (2000). Art as a social system (Translated by Eva M. Knodt). Stanford: Stanford University Press.

Luhmann, N. (2002a). How can the mind participate in communication? In W. Rasch (Ed.), Theories of distinction: Redescribing the descriptions of modernity (pp. 169-184). Stanford, CA: Stanford University Press.

Luhmann, N. (2002b). Einführung in die Systemtheorie, Dirk Baecker (Ed.). Heidelberg: Carl-Auer.

Luhmann, N. (2002c). The modern sciences and phenomenology. In W. Rasch (Ed.), Theories of distinction: Redescribing the descriptions of modernity (pp. 33-60). Stanford, CA: Stanford University Press.

Luhmann, N., Ziegert, K. A., \& Kastner, F. (2004). Law as a social system. Oxford: Oxford University Press.

Malerba, F., Nelson, R., Orsenigo, L., \& Winter, S. (1999). 'History-firendly' models of industry evolution: The computer industry. Industrial and Corporate Change, 8(1), 3-35.

Marx, K. (1971). Das Kapital I. Das Kapital I. Berlin: Dietz.

Marx, K. (1995). Capital I; Abridged Edition. In D. McLellan (Ed.), Oxford: Oxford University Press.

Maturana, H. R. (1978). Biology of language: the epistemology of reality. In G. A. Miller \& E. Lenneberg (Eds.), Psychology and biology of language and thought. Essays in honor of Eric Lenneberg (pp. 27-63). New York: Academic Press.

McGill, W. J. (1954). Multivariate information transmission. Psychometrika, 19(2), 97-116.

Mirowski, P. (2010). Bibliometrics and the modern commercial regime. European Journal of Sociology, 51(2), 243-270.

Mirowski, P., \& Sent, E. M. (2007). The Commercialization of science, and the response of sts. In E. J. Hackett, O. Amsterdamska, M. Lynch, \& J. Wajcman (Eds.), Handbook of Science, technology and society studies (pp. 635-689). Cambridge, MA/London: MIT Press.

Mulkay, M., Potter, J., \& Yearley, S. (1983). Why an analysis of scientific discourse is needed. In K. D. Knorr \& M. J. Mulkay (Eds.), Science observed: Perspectives on the social study of science (pp. 171-204). London: Sage.

Nelson, R. R., \& Winter, S. G. (1977). In search of useful theory of innovation. Research Policy, 6, 35-76.

Nelson, R. R., \& Winter, S. G. (1982). An evolutionary theory of economic change. Cambridge, MA: Belknap Press of Harvard University Press.

Noble, D. (1977). America by design. New York: Knopf.

OECD. (1963, 1976). The measurement of scientific and technical activities: "Frascati Manual". Paris: OECD.

Park, H. W., \& Leydesdorff, L. (2010). Longitudinal trends in networks of university-industry-government relations in South Korea: The role of programmatic incentives. Research Policy, 39(5), 640-649.

Parsons, T. (1963a). On the concept of political power. Proceedings of the American Philosophical Society, 107(3), 232-262.

Parsons, T. (1963b). On the concept of influence. Public Opinion Quarterly, 27(Spring), 37-62.

Parsons, T. (1968). Interaction: I. Social interaction. In D. L. Sills (Ed.), The international encyclopedia of the social sciences (Vol. 7, pp. 429-441). New York: McGraw-Hill.

Parsons, T., \& Platt, G. M. (1973). The American University. Cambridge, MA: Harvard University Press.

Popper, K. R. ([1935], 1959). The logic of scientific discovery. London: Hutchinson.

Powell, W. W., \& DiMaggio, P. J. (Eds.). (1991). The new institutionalism in organizational analysis. Chicago: University of Chicago Press.

Prigogine, I., \& Stengers, I. (1988). Entre le temps et l'éternité. Paris: Fayard.

Schumpeter, J. (1912). The theory of economic development. Oxford: Oxford University Press. 
Schumpeter, J. ([1939], 1964). Business cycles: A theoretical, historical and statistical analysis of capitalist process. New York: McGraw-Hill.

Schumpeter, J. (1943). Socialism, capitalism and democracy. London: Allen \& Unwin.

Schütz, A. (1932). Der sinnhafte Aufbau der sozialen Welt (G. Walsh \& F. Lehnert, Trans. Vol. 1932). Vienna: Springer.

Shannon, C. E. (1948). A mathematical theory of communication. Bell System Technical Journal, 27, 379-423.

Shelton, R. D., \& Leydesdorff, L. (2012). Publish or Patent: Bibliometric evidence for empirical trade-offs in national funding strategies. Journal of the American Society for Information Science and Technology, 63(3), 498-511.

Shinn, T. (2002). The triple helix and new production of knowledge : Prepackaged thinking on science and technology. Social Studies of Science, 32(4), 599-614.

Simon, H. A. (1973). The organization of complex systems. In H. H. Pattee (Ed.), Hierarchy theory: The challenge of complex systems (pp. 1-27). New York: George Braziller Inc.

Slaughter, S., \& Rhoades, G. (2004). Academic capitalism and the new economy: Markets, state, and higher education. Baltimore, MD: Johns Hopkins University Press.

Slezak, P. (1989). Computer discovery and the strong programme. Social Studies of Science, 19, 562-600.

Strand, O., \& Leydesdorff, L. (in preparation). Where is synergy in the norwegian innovation system indicated? Triple helix relations among technology, organization, and geography.

Theil, H. (1972). Statistical decomposition analysis. Amsterdam, London: North-Holland.

Ulanowicz, R. E. (1986). Growth and development: Ecosystems phenomenology. San Jose, etc.: toExcel.

Wagner, C. S. (2008). The new invisible college. Washington, DC: Brookings Press.

Weinstein, F., \& Platt, G. M. (1969). The wish to be free: society, psyche, and value change. Berkeley: University of California Press.

Whitley, R. D. (1984). The intellectual and social organization of the sciences. Oxford: Oxford University Press.

Woolgar, S. (1988). Science. London, Sage: The very idea Beverly Hills.

Woolgar, S., \& Ashmore, M. (Eds.). (1988). Knowledge and reflexivity: New frontiers in the sociology of knowledge. London: Sage.

Wyatt, S. (2010). Digitizing social sciences and humanities: Global challenges and opportunities, World Social Science Report, Paris: UNESCO \& International Social Science Council (pp. 303-306); available online at http://www.unesco.org/new/en/social-and-human-sciences/resources/reports/worldsocial-science-report).

Yeung, R. W. (2008). Information theory and network coding. New York, NY: Springer. 